\title{
REFLECTIONS ON THE CAREER OF PROFESSOR LEWIS KLAR
}

\author{
ELLEN PICARD*
}

TABLE OF CONTENTS

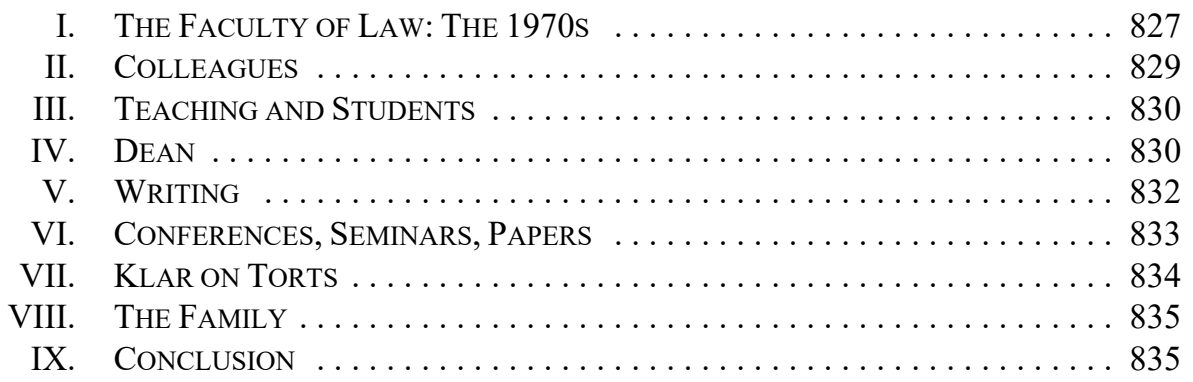

\section{The Faculty OF LAW: The 1970S}

Lewis Klar was just what the Faculty of Law at the University of Alberta needed in 1973. He was, at that time, a Teaching Fellow at Osgoode Hall Law School at York University and was completing his LL.M. at the Institute of Comparative Law at McGill. He was a graduate of McGill University in Law with a B.C.L. and had an Honours B.A. in sociology. He had been admitted to the Law Society of Lower Canada (Quebec). Dean Gerald Fridman had checked him out and he came highly recommended by his teachers and mentors at McGill and at Osgoode Hall. Lewis seemed a perfect addition to the coterie of bright, young people Dean Fridman was hiring to put together a dynamic law school for the 1970s and for the future.

Lewis joined the Faculty as an assistant professor and over the years taught torts, wills, personal property, insurance law, and legal research and writing. I had joined the Faculty a year earlier and was delighted to be teaching torts with this very bright, focused, determined, and personable young man. At the time I had had five years expericence in practice, but did not have a master's degree and I was in awe of his research and library skills. We seemed to have the field of scholarship and practice covered, at least in our own minds! Dean Bowker (so called because of the reverence and respect for him), who had taught me (and just about every other lawyer in Alberta) tort law, was still at the Faculty in 1973 and thankfully was available to us for consultation and research guidance.

Ellen Picard was a professor of law at the University of Alberta from 1972 to 1986 when she was appointed to the Court of Queen's Bench. In 1995 she was appointed to the Alberta Court of Appeal from which she retired in 2016. While at the university she authored two editions of the textbook, Legal Liability of Doctors and Hospitals in Canada. The fifth edition with co-author Professor Gerald Robertson will be available shortly. She created the Health Law Institute in 1977. She was Associate Dean twice and served on the Board of the Alberta Institute of Law Research and Reform and was Vice-President of the Law Reform Commission of Canada. In 1992, the University of Alberta granted her the degree of Honorary Doctor of Laws. 
Looking back, I realize what a remarkable time it was in the Faculty of Law with Dean Bowker, who was its early architect, and the young scholar, Klar, who would play an active part in its evolution, becoming Dean and leading it into the new century. It was a time when there was still respect for the traditional approaches to teaching and learning but also a sense that change was ahead, and had to come, in order to allow us to keep pace with what was happening in the world, and empower us to utilize the amazing technology that we could see just on the horizon. An example was the effect of the remarkable advances in science on tort law and the powerful tool of the computer to organize data and support research and writing. Lewis adapted well to the changes of the late 70s and beyond, using them as the vehicle to support his research, writing, and teaching. He had a keen sense of social responsibility and was alive early on to the responsibility of law for the challenged and the poor. He was truly ahead of the curve in expecting the law to change to meet the demands and assure the rights in a just society.

The hallmark of Lewis' career was hard work. This was one of the ways in which he was a role model in the Faculty. From his first days as the newest member of Faculty until today, when he is sought after as a guest lecturer and speaker, he works as hard and as long as necessary to understand and to get it right. He did not go into classes, meetings, or interviews unprepared. ${ }^{1}$

Lewis has always been a people person. He is a superb communicator and can go to the edge of the dramatic or comedic in making his point. There seems little doubt that Lewis could have made a living as a standup comedian or perhaps, as some students pointed out at the time, could have been "Kotter" in the 1970s sitcom "Welcome Back, Kotter." He was a good listener. His voice and body language told you he wanted to hear what you had to say. He did not posture, or have a hidden agenda, and was always open to new ideas or even a challenge, be it face to face or in print. He was not dogmatic but would stand his ground and defend his position vigorously but fairly. There was no edge to him and he did not personalize issues. However, he would debate and challenge you. If he lost there would be no recriminations. If he won there would be no flaunting — well, not much. However, you might soon afterwards be inundated with case citations, and articles that supported his position. It was the ideal way to learn, test your theories, and prepare to face a classroom of law students, a group of learned colleagues, or perhaps, one day, to write a book.

Lewis' ability and commitment to keep up to date with new law and changes in the law was very strong. He became one of the most effective researchers that I have ever known. In those years, one rarely had the assistance of teaching assistants, or even students. With the development of case books, which Lewis was a moving force in creating, a law professor could get complacent. Sometimes it felt like the challenge of teaching, setting exams, marking, mentoring, preparing materials, and attending meetings left no time to read law. Was it not our primary responsibility to teach black letter law rather than deal with what was possibly the aberrant path through the law taken by some obscure judge? But law was not a dead study as far as Lewis was concerned. He believed in keeping up to date and he wanted

I have a memory of seeing him very, very late one night in his office tapping away on a typewriter while Irene, his soulmate and partner, sat on the floor in the hall, sketching. As it turns out, it is a memory of two exceptional people whose careers would have great impact.

Welcome Back Kotter, 1975, DVD, (Los Angeles, Cal: Shout! Factory, 2004). 
to talk about developments in law or its application. His opening greeting was often, "have you seen the recent decision of..."! Or, you might find a copy of one of the law reports, bookmarked using a recycled bit of paper, standing in your office doorway. I remember distinctly his drawing to my attention cases that dealt with the place of assault in actions against health care professions - and then there was informed consent. We had some delicious debates on many topics. There was even an ongoing debate about the strength of certain courts and judges! His enthusiasm for the most recent pronouncements of the courts was catching. It was no surprise that he became the editor and author of the first and best case reporting series in Canada.

\section{Colleagues}

Lewis set a very high standard for his colleagues. ${ }^{3}$ We talked to each other. A lot. Sometimes it was to test a new approach to teaching an old concept, to get a reaction to an exam question, or to float the idea of a topic for an article. There was both significant insecurity and a little false bravado amongst us. Colleagues were important in allowing us to deal with both extremes. Lewis was secure enough to acknowledge his weaknesses, but trustworthy and reasonable enough to allow us to admit ours.

Lewis' office was a gathering place. It was a place to go whether you wanted to discuss law, or just listen to others do so. ${ }^{4}$ The agenda was not restricted to our host's areas of interest: torts, wills, personal property, and insurance law. I remember it as a place where old and recent constructs of tort law were defined and debated. And so, the seeds were sown for an academic harvest of case comments, articles, and even textbooks for Lewis and others. In tort, specifically it was the scope of duty of care, causation, loss allocation, assessment of damages and compensation, the liability of the Crown, public authorities and professionals, vicarious liability, and statute and tort law. In the beginning, in the pre-Charter ${ }^{5}$ days, the discussions were often infused or captured by current events, the actions of governments or big business, and concern about the rights of individuals.

And so at the Faculty of Law there came to be an appetite for broad-based discussion and debate. The venues became the lunch room, hallways, stairways, and most importantly, classrooms. It was exhilarating, even addictive, and eventually caught on with colleagues teaching other subjects. There is no doubt that Lewis made many of us better professors. This model, so informally generated by professors of the 70s and early $80 \mathrm{~s}$, with Lewis and a few others being the major influences, became a template for the Faculty of Law for at least two decades.

Looking back over a lifelong career in law, I see the years with Lewis Klar and other colleagues of the years between 1972 and 1986 as being unique. We were a family. We laughed together and grieved together. We worked hard, helped each other, and mostly succeeded but sometimes failed. Over the years colleagues left for other universities,

With a distinguished scholar and author as Dean, we were motivated to write and to publish. It was Dean Fridman who set up the connection between the publishers and the neophyte text bookwriters amongst us.

There was a little complaining about low salaries and limited secretarial staff.

Canadian Charter of Rights and Freedoms, Part I of the Constitution Act, 1982, being Schedule B to the Canada Act 1982 (UK), 1982, c 11 [Charter]. 
positions in government or in law firms, or even the bench. The record of the contributions of many whose education and socialization was completed in the "special" professor's graduate school at the Faculty is outstanding. But for Lewis, I do not think that would have happened. To put it another way, with Lewis at the Faculty of Law, it was foreseeable that it would happen.

\section{Teaching And Students}

His students never forget Lewis Klar. Reminiscing brings a smile to their faces and a comment along the lines of, "I did not realize how much I learned in his classes until I needed to know." Some of our students had had successful careers, or a string of university degrees. It was also during these years that we were trying to encourage and foster a broader range of students: aboriginal, mature, physically challenged, professionals such as medical doctors, and members of the police forces. Lewis took a leadership role. He was respectful of the special needs of students and taught by starting out from where they were. Many lawyers whom I have met over the years have told me that Professor Klar made a difference in their lives as students of the law.

Lewis engaged students, and they knew that he cared about whether they learned. He was always prepared, up to date, and not afraid of questions. As a role model for high standards, he inspired the same high standards in his students. He taught ethics in the fabric of a legal subject. He could and did let students know when they were wrong but it was a gentle judgment, never vindictive nor demeaning. There were few boring moments. With his knowledge, complete preparation, and dramatic flare he could make the stories behind the law come alive! He had an open door policy for students and showed great patience with those who were struggling. As Associate Dean for a period in the 1970s and again in the 1980 s, I dealt with many students who had personal and academic challenges. I knew I could count on Lewis to help me, and them, wherever and whenever needed.

A little known fact: following one of Lewis' participations in the annual Law Show at the Faculty of Law - which has spawned a few fairly famous musicians, known actors, and one very successful writer and director - he was scouted by Hollywood to be an understudy to the star in a sequel to the movie "Tootsie"!

Being recognized by colleagues and students is very special. Lewis was given that respectful and well-deserved honour when he was awarded the Honourable Tevie H. Miller Teaching Excellence Award in 2008.

\section{DEAN}

It seemed a natural move for Lewis to become Associate Dean in 1994 and then Dean. It was twenty-four years after his arrival at the Faculty of Law that he became Dean, in 1997. He served until 2002. In Canadian Universities there is a conundrum about whether the best Deans come from within or away. However, as a veteran of Dean selection committees, it 
is my opinion that the best measure of a Dean is that which is within the candidate. Lewis Klar was recognized as the person best able to head the Faculty of Law in 1997.

During the years before he became Dean, he had had the opportunity to experience the workings of a number of other schools, as a visiting professor at the University of Auckland in New Zealand, the University of New South Wales in Australia, Arizona State University, and the University of Western Australia. By 1997, he had served on many professional, government, and community organizations that put him in touch with their work. They included the Canadian Association of Law Teachers (Chair-Torts), the Legal Education Society of Alberta (Director), the Policy Advisory Committee of the Department of Justice, the Human Rights Commission (Consultant), the Environmental Law Centre (Director), the Heritage Fund Scholarship Committee, and key committees of the Law Society. In 1997 he was made an Honorary Bencher of the Law Society of Alberta. Throughout the years prior to becoming Dean, Lewis had become an acknowledged scholar and author with his own textbook, Tort Law, ${ }^{7}$ an invited co-author of tort case books with the highly respected Justice Linden, and editor of Canadian Cases on the Law of Torts. His other writing is reviewed below.

Lewis brought the same outstanding attributes he had as a professor to the position of Dean: hard work, incredible social intelligence, and self-confidence. He was well known and respected by the bar, the bench, within university communities across Canada, and even internationally and by government.

Because he appreciated the history of the Faculty of Law, he understood the importance of preserving it, but he also wanted to "grow" the law school. He believed it was important to awaken alumni to a commitment to their school, and knew how to support and encourage a high level of scholarship for which he was the role model. He wanted to make the law school an ever more important player in the University and in Alberta. However, he had a new vision. He wanted to take the Faculty of Law out to the world and bring the world in. His travels to other universities and countries supported his goal of contacting alumni in other parts of the world and also allowed him to encourage scholars and professors to visit the Faculty of Law. Of note is the relationship he developed with universities in Japan and India.

His tireless work with alumni abroad and at home, resulted in a very successful fundraising program that laid the groundwork for the future. One example is the creation of the Decore Mediation Centre. The law school now bristles with plaques telling of the contributions of alumni.

The library was a crucial resource to Lewis as a young professor in 1973 and it remained very important to him. He called it the "jewel" of the Faculty. There were a number of Institutes housed at the Faculty of Law in 1997; he was very supportive of them without giving any preferential treatment. I know, as I founded one of them: the Health Law Institute. He encouraged and supported new courses at the law school and outreach programs to encourage undergraduate and graduate students to come to the Faculty. He worked with 
faculty to set up new courses to embrace human rights and the spirit of the Charter, and reflect change that was taking place in the law and in public attitudes. He encouraged the setting-up of a lecture and seminar program and the inviting of the greater university community and the public to the law school. It was the response of a great law school to individual and societal needs for legal recognition and protection.

Lewis was very successful in making the Faculty a welcome place for the bar and the bench. In part, this was because he sought to meet people and attended every meeting and social occasion to which he was invited. He also spoke at educational seminars set up by the bar and bench. During his tenure, sessional instructors were made to feel very welcome and brought a practical aspect to the learning of students. Many members of the judiciary spent some months visiting, speaking to, and advising students.

Lewis as an administrator and the face of the Faculty of Law had a collaborative, respectful style. He acted in the best interests of the students, professors, and alumni of the Faculty of Law. He had no vested self-interest that set the agenda or was the focus of his tireless work. He accepted the fact that being Dean and advancing the best interests of the Faculty of Law was his full-time job. He had a positive attitude and inclusive approach. He remained accessible to students and continued to teach. He was known to be totally unselfish about time spent assisting young professors. He found the time to mentor, encourage, and support them as they got established, sought research opportunities and financing. Lewis was respected and well-liked in the university community. He served on many of the most important committees and was often consulted by other Deans and the President.

The only thing that is constant is change. Lewis Klar changed the Faculty of Law for the better. During his Deanship he made it stronger: academically, financially, and as a positive force in the university and legal community.

Even after he left the position of Dean, Lewis remained one of the outstanding ambassadors for the Faculty, visiting and teaching at the College of Law in Hyderbad, India, the National Law School of India at Bangalore, the University of San Diego School of Law, the University of British Columbia, and McGill University. After his retirement, he became a member of the adjunct faculty at the Sandra Day O'Connor College of Law at Arizona State University.

Lewis was awarded a number of honours during the years in which he was the Dean. He was given the Queen's Counsel designation, the Certificate of Merit of the Law Society of Alberta, the Distinguished Service Award for Legal Scholarship by the Law Society of Alberta and the Canadian Bar Association, and he was elected a member of the American Law Institute.

\section{WRITING}

The environment at the Faculty of Law in the early 1970s encouraged and supported writing. Typically, a young professor began with a comment on a case or an article in a law review. Many went on to write articles in prestigious law journals, chapters in books, and, eventually, textbooks. Lewis followed this path and was one of the most prodigious. His ability and potential were recognized throughout the years by a number of research grants 
including, in his early years, Institute of Law Research and Reform and University of Alberta Grants, and a Canada Council Grant. Further along in his career he was awarded a Foundation for Legal Research Grant from the University of British Columbia. He was also awarded the Borden Ladner Gervais Research Fellowship.

The first article written by Lewis was published in an academic journal in 1974. There followed many others covering changes and challenges in the law. They were published in recognized law reports and reviews and were well-known and well-used in academia and also by the bar and bench.

Of great assistance to practicing lawyers and judges are case comments. They are a special challenge to academic writers because they must know not only the DNA of the law involved, but also the context for its application and the legal landscape within which it will operate. Often one must first teach because the reader may not know or remember the law, or it may be new law or a new or unique application of old law. Recognizing that the adversary system is the modus operandi for the legal profession, the best case comments are those that are balanced yet provide the reasoned position of the academic author. Lewis Klar came to be recognized and highly respected for his case notes and annotations published as editor of Canadian Cases on the Law of Torts and Studies in Canadian Tort Law through the years 1976 to 1979 inclusive, and as a consultant on Remedies in Tort.

The Faculty of Law was the home of the highly-respected Alberta Law Reform Institute and Lewis was a great resource for it. He provided reports on: Defence of Fair Comment; Inter-Spousal Tort Immunity; Guest Passenger Legislation; The Contributory Negligence Act; and The Tort-Feasors Act.

\section{Conferences, Seminars, Papers}

Lewis was and still is a much sought after guest lecturer, keynote speaker, and presenter at seminars and meetings. The number and diversity of the topics that he has covered are impressive. He always knows his topic, is prepared to provide a paper, and can be counted on to be stimulating, even entertaining. None of these attributes are a surprise to his former students and colleagues. It is clear that he deserves credit for keeping students, lawyers, and judges all over North American updated on tort law. But he has done much more. His depth of knowledge about tort law comes from being an academic, a lawyer, and student of society and modern life.

The range of topics that he has taught, discussed, debated, and written papers about have involved Lord Atkin's Neighbour Principle (was there a snail in the bottle of ginger beer?), the death of res ipsa loquitur (does its ghost exist?), the thin skull principle (still causing headaches for the bar and bench), and whether "no-fault" is a viable alternative (although it is not healthy in New Zealand). Skimming through the long list of titles, key words jump out: the environment; waste disposal; products liability; reproductive drugs and devices; tobacco; the Church of Scientology; and Melvin Belli. Lewis has given papers and talks on some of the issues that continue to pose a challenge, such as the liability of professions, public authorities, and the Crown. The insurance industry, manufacturers, and those involved in construction and building inspection are all greatly affected by developments in tort law and the relationship between tort and contract law, and Lewis has instructed them. One of Lewis' 
biggest contributions has been his writing, teaching, and lecturing on the difficult duo that are key parts of the negligence equation namely, the scope of duty of care and the analysis of causation and the resulting consequences to liability and compensation.

It is no surprise that Lewis came to be sought after by major publishers and legal authors. He wrote a number of chapters in textbooks, but his most notable union was with the Honourable Allen Linden, who as professor and then judge had authored textbooks that were widely used for teaching, or learning tort law in Canada. Lewis became co-author for editions eight through fourteen of Canadian Tort Law: Cases, Notes \& Materials. ${ }^{8}$

\section{KLAR ON TORTS}

Writing his own textbook was the natural culmination of Lewis' teaching, writing, lecturing, consulting, research, and scholarship. Signing a contract to write a book is, however, rather like signing up to be crew on a racing yacht or to take sky-diving lessons. To put it in negligence terms: you realize you have taken on a duty of care; you are paralyzed by the standard of care involved; it seems foreseeable that you will not meet the standard of care and therefore it is entirely foreseeable that there will be injury to others - who "but for" your unrealistic, egotistical overvaluation of your abilities would not suffer. ${ }^{9}$

The textbook, Tort Law ${ }^{10}$ came out in 1991. It is now in its 5th edition. As with all his writing over the years, his textbook, in modern terms, is very user-friendly. His writing is clear and unpretentious. Lewis makes his points logically and his perspective is balanced. He does not hang you up with a "watch me think" approach. If the reader needs some context, he gives it without getting mired in minutiae. Anyone who has written in the legal field knows how much harder it is to write in "plain language" so that you teach and inform without the clutter of excess wordage, muddled thoughts, or strained logic. A key factor in assessing the writing of a legal scholar is trust. Whether you are a student tort-neophyte or professor tortaholic, a first year law student looking up "duty of care," or a battle-scarred barrister looking for weighty but helpful interpretations of the Supreme Court of Canada on causation, the Klar text is solid. You know that the information, analysis, and opinion in it are trustworthy. This textbook is comprehensive, authoritative, and highly regarded. Wellrespected commentators have said that it is unique in tackling issues which so often are swept under the carpet. Lewis does not gloss over problems and conflicts. He has always had a keen intellectual curiosity, and his broad experience with the key players in legal institutions and with people has given him a basis upon which to describe and dissect complex issues in tort law. His goal as a young professor to stay abreast of developments in law has anchored his writing over the years and means that his writing is up to date. Lewis has accepted the heavy responsibility of commenting when he believes a court or a judge has "got it wrong." However, he does it with respect and a tone of constructive criticism.

For the last two editions Linden and Klar were joined by another well-known and respected torts scholar, Professor Feldthusen.

Speaking for myself, I wondered whether my two mentors, Deans Wilbur Bowker and Gerald Fridman might be contributorily negligent.

10 Lewis N Klar, Tort Law (Toronto, Ont: Carswell, 1991). 
Klar's Tort Law has been cited extensively (a modest and dated count would be approaching 1,000 times), and expansively by all levels of court in Canada, the House of Lords, and many common law courts. It has been used to define, determine, decide, and distinguish. Counsel have confidence citing it and judges use it to support analysis and reasons. In the legal world there is now a great deal of information available. Unfortunately, there are few maps to provide a path or lenses to facilitate a focus. It is the book that starts the law students on their studies of the law of torts and guides them during their articles; that is consulted by practicing lawyers as they provide advice and prepare for litigation; and by judges trying to understand the lawyers and make decisions that are fair and just. It is a "jewel."

It is significant and appropriate that Professor Klar has recently been awarded one of the most prestigious prizes in tort law, the John G. Fleming Award in Torts, that honours the well-known and highly regarded tort scholar and author. This award is delivered every two years and recognizes outstanding contributions to tort scholarship. A previous winner was the Honourable Allen Linden. Lewis will be receiving the award in the Fall of 2016 at the University of California School of Law where he will deliver the Fleming Lecture.

\section{THE FAMILY}

A reflection on the life and contributions of Lewis Klar is not complete without recognizing Lewis' partner, soulmate, and the love of his life, Irene. I think of her as a member of that group of 1973 because, although engaged in a different discipline, she was a friend, counsellor, and hostess to so many. Over the years Lewis and Irene have been inseparable. She is his greatest fan and best friend.

Irene Klar is a famous artist whose work is in the collections of universities, art galleries, major banks, hotels, and businesses. Her art is on cards, clothing, ornaments, and posters. It is a source of great pride to be able to say that you own a "Klar" (and of course that is also true of a certain textbook with a similar name)! Even through their very busy lives, Lewis and Irene have been involved and loving parents. Their children Samara and Noah are making their own contributions to the world. Samara is a professor of political science at the University of Arizona who has received numerous awards for her research and is highly regarded by her students. Noah is an actor, talented song-writer and musician whose songs and videos have delighted children and their parents. As a director of the Ontario Trillium Foundation, a large community outreach, educational and funding organization, he contributes to the lives of others. Lewis and Irene have three young grandchildren amongst whom there will, no doubt, be a professor and an artist.

\section{CONCLuSion}

It has been a privilege, and real fun, to have had the opportunity to reflect on the contributions of Lewis Klar. We were colleagues for 15 years as professors at the Faculty of Law during which time, as he, I took on administrative duties. Thanks to his paving the way, I was welcomed by universities overseas in New Zealand, Australia, and Hong Kong. Upon my appointment to the bench in 1986, I continued to be linked to the Faculty through sessional teaching, the mooting program, the alumni program, and through contact with the Health Law Institute. My judicial career has included responsibilities in teaching judges, law 
reform and writing, including that of a textbook. During my career of 29 years as a judge, Lewis and I have remained great friends. We have been law students together for 42 years.

Dear Lewis, you have made a difference in this world. I am proud to be your friend and grateful to have been a participant on your journey. 